\title{
Article
}

\section{The Mediating Role of Lean Soft Tissue in the Relationship between Somatic Maturation and Bone Density in Adolescent Practitioners and Non-Practitioners of Sports}

\author{
Ricardo R. Agostinete ${ }^{1, *} \mathbb{D}$, André $O$. Werneck ${ }^{2} \mathbb{D}$, Santiago Maillane-Vanegas ${ }^{1}$, Luis Gracia-Marco ${ }^{3,4} \mathbb{D}$, \\ Esther Ubago-Guisado $^{3,4,5}{ }^{(0}$, Annie M. Constable ${ }^{6,7}$, Romulo A. Fernandes ${ }^{1}$ and Dimitris Vlachopoulos ${ }^{6}(\mathbb{C})$ \\ 1 Laboratory of InVestigation in Exercise (LIVE), Department of Physical Education, \\ Sao Paulo State University (UNESP), Presidente Prudente 19060-900, Brazil; \\ santiagovanegas16@gmail.com (S.M.-V.); romulo.a.fernandes@unesp.br (R.A.F.) \\ 2 Center of Epidemiological Research in Nutrition and Health, Department of Nutrition, \\ School of Public Health, University of São Paulo, São Paulo 01246-904, Brazil; andreowerneck@gmail.com \\ 3 PROFITH "PROmoting FITness and Health through Physical Activity", Research Group, Sport and Health \\ University Research Institute (iMUDS), Departament of Physical Education and Sport, Faculty of Sport \\ Sciences, University of Granada, 18071 Granada, Spain; lgracia@ugr.es (L.G.-M.); \\ esther.ubago@gmail.com (E.U.-G.) \\ check for \\ updates \\ Citation: Agostinete, R.R.; Werneck, \\ A.O.; Maillane-Vanegas, S.; \\ Gracia-Marco, L.; Ubago-Guisado, E.; \\ 4 Instituto de Investigación Biosanitaria ibs GRANADA, 18012 Granada, Spain \\ 5 Escuela Andaluza de Salud Pública (EASP), 18011 Granada, Spain \\ 6 Children's Health and Exercise Research Centre, Sport and Health Sciences, University of Exeter, \\ Exeter EX1 1TX, UK; ac857@exeter.ac.uk (A.M.C.); D.Vlachopoulos@exeter.ac.uk (D.V.) \\ 7 Institute of Biomedicine, Kuopio Campus, University of Eastern Finland, FI-70211 Kuopio, Finland \\ * Correspondence: ricardo.agostinete@unesp.br; Tel.: +55-(18)-3229-5710
} Constable, A.M.; Fernandes, R.A.; Vlachopoulos, D. The Mediating Role of Lean Soft Tissue in the

Relationship between Somatic Maturation and Bone Density in Adolescent Practitioners and Non-Practitioners of Sports. Int. J. Environ. Res. Public Health 2021, 18, 3008. https://doi.org/10.3390/ ijerph18063008

Academic Editor: Paul B. Tchounwou

Received: 15 February 2021

Accepted: 10 March 2021

Published: 15 March 2021

Publisher's Note: MDPI stays neutral with regard to jurisdictional claims in published maps and institutional affiliations.

Copyright: (c) 2021 by the authors. Licensee MDPI, Basel, Switzerland This article is an open access article distributed under the terms and conditions of the Creative Commons Attribution (CC BY) license (https:/ creativecommons.org/licenses/by/ $4.0 /)$

\begin{abstract}
This study aimed to identify the mediating effect of lean soft tissue (LST) in the association between somatic maturation and areal bone mineral density (aBMD) in adolescents by sex and sport participation. The sample included 558 adolescents (401 males, mean age of 14.0 years) that were practitioners of sports (11 sport modalities, $n=402)$ and a non-sport group $(n=157)$. Somatic maturation was assessed by using a validated peak height velocity prediction equation. Dual-energy X-ray absorptiometry (DXA) was used to assess aBMD (upper and lower limbs, spine and total body less head-TBLH) and LST. For both sexes, LST mediated the association between somatic maturation and $\mathrm{aBMD}$ at all skeletal sites (mediation percentage ranging from $36.3 \%$ to $75.4 \%$ ). For sport and non-sport groups, the LST also mediated the association between somatic maturation and aBMD at all skeletal sites (mediation percentage ranging from $51.6 \%$ to $85.6 \%$ ). The direct effect was observed in all groups, except for lower limbs and TBLH in the non-sport group. The association between somatic maturation and aBMD was mediated by LST in adolescents of both sexes and regardless of involvement in organized sports. Our findings highlighted the role of improving LST to mitigate the association of somatic maturation with aBMD.
\end{abstract}

Keywords: bone health; youth; team sport; exercise

\section{Introduction}

During human growth, biological maturation affects all tissues of the human body, including lean soft tissue (LST) (muscle tissue) and adipose tissue [1]. Biological maturation also affects the bone tissue through bone mass accrual [1] and bone fracture incidence [2,3]. LST has an important metabolic, locomotive and physiological role with areal bone mineral density (aBMD), mainly due to mechanotransduction forming a "bone-muscle unit" [4]. Bone tissue has important functions of support, movement, protection, blood cell production and homeostatic regulation of minerals [5], while LST is also responsible for locomotion, stability and is the major repository of protein [6]. These variables are in effect especially during adolescence, when several morphological and functional changes occur 
due to maturation events [1], including peak height velocity (PHV). PHV is a common landmark of somatic maturation that is considered as the period of maximum growth in stature. The PHV is especially important for bone tissue considering that during the circumpubertal years ( -2 to +2 years from $\mathrm{PHV}$ ), around $33-46 \%$ of the total bone mass observed in adulthood is acquired [7]. Moreover, bone mineral content (BMC) and areal bone mineral density (aBMD) are positively related to somatic maturation in both cross-sectional [8] and longitudinal [9] studies.

Among the determinants of bone outcomes in adolescents, the literature has shown that LST is the strongest predictor of aBMD [10] due to the osteogenic effect of muscle contractions on bone [11], causing strains and mechanical loading of muscle on bones during body movements. Moreover, LST is closely related to the biological maturation process. It is known that the peak accrual of lean mass follows the PHV and precedes the peak accrual of bone mass [12]. Thus, LST is an important determinant of aBMD. In this sense, LST could be considered a potential mechanism underlying the association between biological maturation and aBMD [12].

Different studies assessing the association between biological maturation and bone aspects are limited in that only the direct association between timing and status of maturation on bone variables was assessed [13-15]. However, the potential mediating role of LST in the association between somatic maturation, an indicator of biological maturation, and aBMD has not been investigated in adolescents who practice sports. Moreover, there is a lack of evidence on which covariates are more appropriate in bone studies in pediatric populations; somatic maturation, LST or both.

The association among somatic maturation, LST and aBMD is particularly important for adolescent practitioners of sports because LST plays an important, mediating role in the association between physical fitness and bone outcomes [16]. Besides that, sports participation involves a great number of muscle contractions, which generate forces and mechanical loads responsible for the bone adaptations [17]. Thus, the aim of this study was to examine the mediating role of LST on the relationship between somatic maturation and aBMD in adolescents considering the sex and sport participation.

\section{Materials and Methods}

\subsection{Sample}

This cross-sectional study is part of a large study (Analysis of Behaviors of Children During Growth-ABCD Growth Study) from the Laboratory of InVestigation in Exercise (LIVE) that was conducted in the city of Presidente Prudente (Brazil) from October 2013 to May 2017.

At the beginning of the study, a cooperation agreement was established between the LIVE and local authorities. After explaining the proposal to private/public schools and sports institutions, the researchers were given formal authorization to start data collection and adolescents were regularly registered and invited to be part of the research. To participate in the study, adolescents were required to provide a written consent form signed by a parent or guardian. The Ethical Board of the São Paulo State University (UNESP) approved the investigation (Process numbers 1.677.938/2016 and 02891112.6.0000.5402).

The sample was composed of 558 adolescents (401 males) with a mean age of 14.1 years $( \pm 2.0)$. The non-sport group included 156 adolescents (109 males) while the sport group included 402 adolescents, divided as follows: basketball $(n=53$ males), soccer $(n=101$ males), swimming $(n=58$ (males $n=40))$, volleyball $(n=33$ (males $n=2))$, karate $(n=36$ (males $n=19))$, judo $(n=48$ (males $n=30)$ ), kung fu $(n=30$ (males $n=21)$ ), baseball $(n=12$ males), gymnastics ( $n=10$ females), tennis ( $n=6$ males) and track and field ( $n=15$ (males $n=9)$ ).

The inclusion criteria to be eligible were (1) chronological age between 10 and 18 years; (2) a minimum of 6 months of participation in the specific sport (sport group); (3) a minimum engagement of three or more hours per week (sport group); (4) non-involvement in other organized sports (sport groups); (5) the absence of engagement in organized sport 
(presence of coach, training routine and competitions (non-sport group)); (6) the consent forms were signed by parents and guardians of the participants.

\subsection{Body Composition Measures}

Dual-energy X-ray absorptiometry (DXA) (Lunar DPX-NT; General Electric Healthcare, Little Chalfont, Buckinghamshire, UK) with GE Medical System Lunar software (version 4.7) was used to obtain areal bone mineral density $\left(\mathrm{aBMD}, \mathrm{g} / \mathrm{cm}^{2}\right)$, lean soft tissue (LST, kg) (sum of all soft tissue, bone-free and fat-free) and fat mass $(\mathrm{kg})$, measured at the university laboratory in a temperature-controlled room. A trained researcher performed all scans and tested the scanner quality before the first exam of each day. The scans were performed using a standardized protocol with the participants remaining in the supine position and wearing only light clothing, without shoes. Regional analysis for aBMD of upper limbs, lower limbs, spine and total body less head (TBLH) occurred off-line after the scans took place [18]. The coefficient of variation for this device was $0.66 \%$ (in total-body aBMD analysis, $n=30$ participants not involved in this study), setting the lines (region of interest-roi) in the segments (upper limbs, lower limbs and spine) as requested for the General Electric Healthcare company and stated in previous studies [19].

\subsection{Anthropometry}

A stadiometer (Sanny, model American Medical of the Brazil Ltd., Brazil; accurate to $0.1 \mathrm{~cm}$ ) was used to measure height and sitting height to later allow an estimate of leg length and subsequent maturity offset. An electronic scale (Filizzola PL 150, model Filizzola Ltd., Brazil; with a precision of $0.1 \mathrm{~kg}$ ) was used to obtain body mass. The measures were assessed using standardized techniques described in the literature [20] and by a trained researcher.

\subsection{Somatic Maturation}

Anthropometric measurements (body mass and stature) were used to estimate years from the peak height velocity (PHV) through mathematical formulas predicted by Moore et al. [21]. This measure denotes the distance (in years) from the PHV, a landmark of somatic maturation that is considered the period of maximum growth in stature. Negative values denote that the individual has not yet passed the PHV, and positive values denote that the individual has already passed the PHV. The coefficient of determination has been reported in the literature $\left(\mathrm{r}^{2}=0.898\right.$, Standard error of the estimate-SEE $=0.5$ in females and $\mathrm{r}^{2}=0.896$, SEE $=0.5$ in males) [21]

\subsection{Statistical Analysis}

Characteristics of the sample were expressed as mean values, standard deviation (SD) and $95 \%$ confidence intervals ( $95 \% \mathrm{CI}$ ). Sex and sport participation differences in descriptive variables were tested using the Mann-Whitney test. Pearson correlation coefficients were used to find associations between the independent, mediator and dependent variables. For mediation models, we used the model proposed by Valeri and Vanderweele [22]. The theoretical model is presented in Figure 1. In this method, the total effect (i.e., the effect of somatic maturation on $\mathrm{aBMD}$ ) is decomposed into controlled direct effects (i.e., the direct effect of somatic maturation on aBMD through pathways not related to LST), reference interaction (i.e., the effect of somatic maturation on aBMD due to the interaction with LST), mediated interaction (i.e., the effect of somatic maturation on aBMD due to both mediation by and interaction with LST) and pure indirect effects (i.e., the effect of somatic maturation on aBMD mediated by LST). All the correlation and mediation models were adjusted for the same variables, aiming to reduce the potential role of confounders. Considering that there is variability in aBMD, to control for the engagement in different types of sports [23], all the analyses were adjusted by sport modality, aiming to control for variations due to sport. We acknowledge that this will not physiologically remove the effect of different sports, which we could not control, but it removes the statistical differences in aBMD to 
allow us to perform the specific analyses. Thus, the analysis by sex was adjusted by sport modality, while analysis by sport participation was adjusted by sex and sport modality. The command "med4way" on Stata 15.1 was used [24] and the level of significance was set at $p<0.05$.

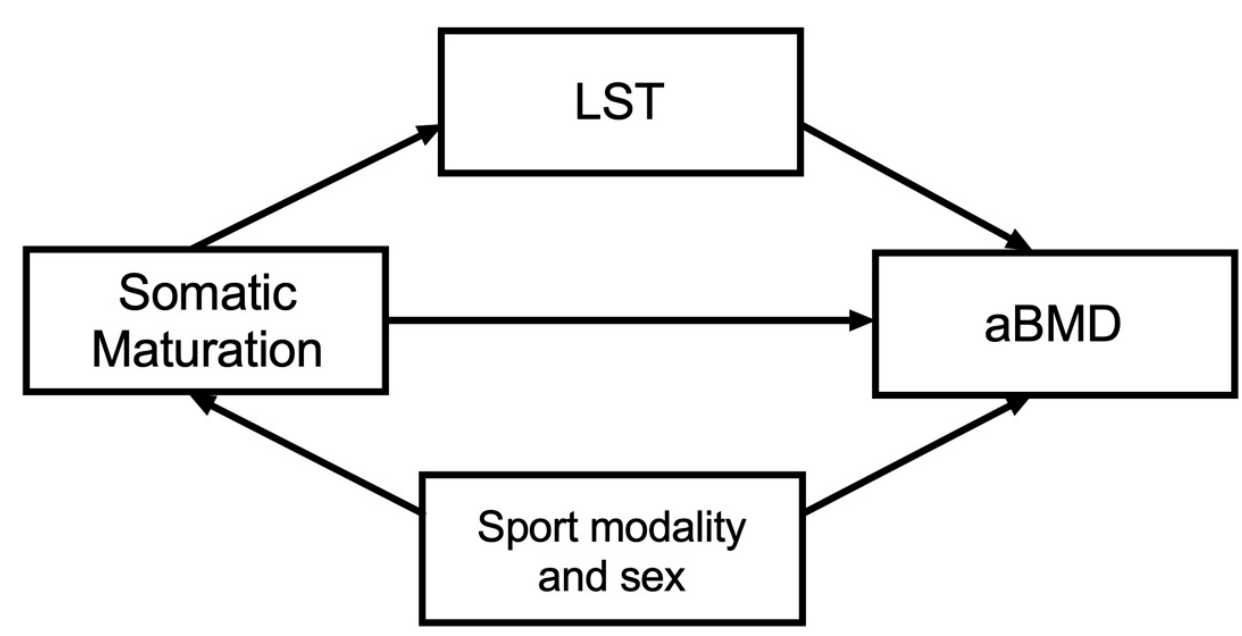

Figure 1. Theoretical model. Independent variable: somatic maturation; dependent variable: areal bone mineral density (aBMD); mediator variable: lean soft tissue (LST). Confounders: sex and sport modality.

\section{Results}

Table 1 presents the characteristics of the sample. In the crude analysis by sex, females presented an advanced somatic maturation $(1.76 \pm 1.67$ years in females vs. $0.69 \pm 1.71$ years in males) as well as lower LST ( $33.7 \pm 5.4 \mathrm{~kg}$ in females vs. $45.5 \pm 11.3 \mathrm{~kg}$ in males) and aBMD $\left(\mathrm{g} / \mathrm{cm}^{2}\right)$ at all body sites (upper limbs: $0.766 \pm 0.091$ in females vs. $0.813 \pm 0.140$ in males; lower limbs: $1.166 \pm 0.118$ in females vs. $1.286 \pm 0.205$ in males and TBLH: $0.955 \pm 0.100$ in females vs. $1.061 \pm 0.155$ in males), except in the spine $\left(1.078 \pm 0.151 \mathrm{~g} / \mathrm{cm}^{2}\right.$ in females vs. $1.025 \pm 0.173$ in males). In the analysis by sport participation, the groups presented the same somatic maturation stage $(p=0.555)$. The sport group had a higher LST ( $43.7 \pm 11.6 \mathrm{~kg}$ in sport group vs. $38.3 \pm 9.7 \mathrm{~kg}$ in non-sport group) and aBMD at all body sites (upper limbs: $0.813 \pm 0.134$ in sport group vs. $0.764 \pm 0.112$ in non-sport group; lower limbs: $1.279 \pm 0.196$ in sport group vs. $1.182 \pm 1.164$ in non-sport group; spine: $1.056 \pm 0.162$ in sport group vs. $0.997 \pm 0.177$ in non-sport group and TBLH: $1.063 \pm 0.146$ in sport group vs. $0.989 \pm 0.127$ in non-sport group.)

Table 2 presents the partial correlations between exposure, mediator and outcomes by sex (adjusted by sport modality) and sport participation (adjusted by sex and sport modality). In all analyses by sex and sport participation, somatic maturation presented a strong positive correlation with LST ( $r=0.593$ to 0.920$)$ as well as aBMD at all skeletal sites $(r=0.554$ to 0.820$)$. Moreover, LST presented a strong positive correlation with aBMD at all skeletal sites ( $r=0.609$ to 0.863$)$ in males, females, the sport group and the non-sport group.

Table 3 and Figure 2 present the sex-specific mediation effects of LST in the association between somatic maturation and aBMD at different skeletal sites. The significant variables in the correlation analysis were inserted in the mediation models. In all models, for both sexes, LST mediated the association between somatic maturation and aBMD in the upper limbs (70.8\% for boys and $58.8 \%$ for girls), lower limbs (68.1\% for boys and $58.0 \%$ for girls), spine ( $72.2 \%$ for boys and $36.3 \%$ for girls) and TBLH ( $75.4 \%$ for boys and $59.8 \%$ for girls). The direct effect remained significant for all aBMD variables and in both sexes $(p>0.05)$. 
Table 1. Characteristics of the sample according to sex and sport participation $(n=558)$.

\begin{tabular}{|c|c|c|c|}
\hline Total $(n=559)$ & $\begin{array}{c}\text { Males }(n=401) \\
\text { Mean } \pm \text { SD }\end{array}$ & $\begin{array}{c}\text { Females }(n=157) \\
\text { Mean } \pm \text { SD }\end{array}$ & $p$ \\
\hline Chronological age, years & $14.2 \pm 2.0$ & $14.0 \pm 2.0$ & 0.336 \\
\hline Somatic maturation *, years & $0.69 \pm 1.71$ & $1.76 \pm 1.67$ & $<0.001$ \\
\hline Age at PHV, years & $13.5 \pm 0.6$ & $12.3 \pm 0.6$ & $<0.001$ \\
\hline Body mass, $\mathrm{kg}$ & $60.1 \pm 15.3$ & $53.1 \pm 12.1$ & $<0.001$ \\
\hline Stature, $\mathrm{cm}$ & $168.4 \pm 12.4$ & $159.5 \pm 8.9$ & $<0.001$ \\
\hline LST, $\mathrm{kg}$ & $45.5 \pm 11.3$ & $33.7 \pm 5.4$ & $<0.001$ \\
\hline Body fat, kg & $10.8 \pm 8.4$ & $16.3 \pm 8.7$ & $<0.001$ \\
\hline Upper limbs aBMD, $\mathrm{g} / \mathrm{cm}^{2}$ & $0.813 \pm 0.140$ & $0.766 \pm 0.091$ & 0.003 \\
\hline Lower limbs aBMD, $\mathrm{g} / \mathrm{cm}^{2}$ & $1.286 \pm 0.205$ & $1.166 \pm 0.118$ & $<0.001$ \\
\hline Spine $\mathrm{aBMD}, \mathrm{g} / \mathrm{cm}^{2}$ & $1.025 \pm 0.173$ & $1.078 \pm 0.151$ & $<0.001$ \\
\hline \multirow[t]{2}{*}{ TBLH aBMD, $\mathrm{g} / \mathrm{cm}^{2}$} & $1.061 \pm 0.155$ & $0.995 \pm 0.100$ & $<0.001$ \\
\hline & Sport Group $(n=402)$ & $\begin{array}{l}\text { Non-sport Group } \\
\quad(n=156)\end{array}$ & \\
\hline Chronological age, years & $14.0 \pm 1.9$ & $14.4 \pm 2.4$ & 0.088 \\
\hline Somatic maturation *, years & $0.97 \pm 1.68$ & $1.06 \pm 1.97$ & 0.555 \\
\hline Age at PHV, years & $13.1 \pm 0.8$ & $13.3 \pm 0.9$ & $<0.001$ \\
\hline Body mass, $\mathrm{kg}$ & $59.4 \pm 14.8$ & $54.8 \pm 14.2$ & 0.001 \\
\hline Stature, $\mathrm{cm}$ & $166.9 \pm 12.3$ & $163.4 \pm 11.8$ & 0.004 \\
\hline LST, kg & $43.7 \pm 11.6$ & $38.3 \pm 9.7$ & $<0.001$ \\
\hline Body fat, kg & $12.1 \pm 8.9$ & $12.9 \pm 8.8$ & 0.381 \\
\hline Upper limbs aBMD, $\mathrm{g} / \mathrm{cm}^{2}$ & $0.813 \pm 0.134$ & $0.764 \pm 0.112$ & $<0.001$ \\
\hline Lower limbs aBMD, $\mathrm{g} / \mathrm{cm}^{2}$ & $1.279 \pm 0.196$ & $1.182 \pm 0.164$ & $<0.001$ \\
\hline Spine $\mathrm{aBMD}, \mathrm{g} / \mathrm{cm}^{2}$ & $1.056 \pm 0.162$ & $0.997 \pm 0.177$ & $<0.001$ \\
\hline TBLH aBMD, $\mathrm{g} / \mathrm{cm}^{2}$ & $1.063 \pm 0.146$ & $0.989 \pm 0.127$ & $<0.001$ \\
\hline
\end{tabular}

PHV, peak of height velocity; aBMD, areal bone mineral density; LST, lean soft tissue. * , years from PHV; TBLH, total body less head.

Table 2. Partial correlations of independent, mediator and dependent variables according to sex and sport participation.

\begin{tabular}{|c|c|c|c|c|c|}
\hline & LST & $\begin{array}{l}\text { Upper } \\
\text { Limbs } \\
\text { aBMD }\end{array}$ & $\begin{array}{l}\text { Lower } \\
\text { Limbs } \\
\text { aBMD }\end{array}$ & Spine aBMD & $\begin{array}{l}\text { TBLH } \\
\text { aBMD }\end{array}$ \\
\hline & $r / p$-Value & $r / p$-Value & $r / p$-Value & $r / p$-Value & $r / p$-Value \\
\hline \multicolumn{6}{|l|}{$\begin{array}{c}\text { Somatic } \\
\text { Maturation }\end{array}$} \\
\hline Males & $0.898 /<0.001$ & $0.731 /<0.001$ & $0.818 /<0.001$ & $0.744 /<0.001$ & $0.820 / 0.001$ \\
\hline Females & $0.593 /<0.001$ & $0.554 /<0.001$ & $0.576 /<0.001$ & $0.619 /<0.001$ & $0.599 /<0.001$ \\
\hline Sport group & $0.920 /<0.001$ & $0.690 /<0.001$ & $0.792 /<0.001$ & $0.680 /<0.001$ & $0.781 /<0.001$ \\
\hline $\begin{array}{l}\text { Non-sport } \\
\text { group } \\
\text { LST }\end{array}$ & $0.813 /<0.001$ & $0.648 / 0.001$ & $0.647 /<0.001$ & $0.719 /<0.001$ & $0.665 /<0.001$ \\
\hline Males & - & $0.770 /<0.001$ & $0.840 /<0.001$ & $0.771 /<0.001$ & $0.863 /<0.001$ \\
\hline Females & - & $0.683 /<0.001$ & $0.704 /<0.001$ & $0.609 /<0.001$ & $0.744 /<0.001$ \\
\hline Sport group & - & $0.681 /<0.001$ & $0.757 /<0.001$ & $0.647 /<0.001$ & $0.761 /<0.001$ \\
\hline $\begin{array}{l}\text { Non-Sport } \\
\text { group }\end{array}$ & - & $0.700 /<0.001$ & $0.735 /<0.001$ & $0.701 /<0.001$ & $0.750 /<0.001$ \\
\hline
\end{tabular}

Analysis by sex adjusted by sport modality. Analysis by sport participation adjusted by sex and sport modality. aBMD, areal bone mineral density; PHV, peak height velocity; LST, lean soft tissue; TBLH, total body less head. 
Table 3. Mediation models of the association between somatic maturation and aBMD by LST according to sex.

\begin{tabular}{|c|c|c|c|c|c|}
\hline & Total Effect & $\begin{array}{l}\text { Controlled } \\
\text { Direct Effect }\end{array}$ & $\begin{array}{l}\text { Reference } \\
\text { Interaction }\end{array}$ & $\begin{array}{l}\text { Mediated } \\
\text { Interaction }\end{array}$ & $\begin{array}{c}\text { Pure Indirect } \\
\text { Effect }\end{array}$ \\
\hline \multicolumn{6}{|l|}{ aBMD } \\
\hline \multirow{3}{*}{ Upper limbs } & 0.00602 & 0.00176 & -0.00005 & 0.00005 & 0.00427 \\
\hline & $\begin{array}{c}(0.00548 \text { to } \\
0.00657)\end{array}$ & $\begin{array}{c}(0.00081 \text { to } \\
0.00271)\end{array}$ & $\begin{array}{c}(-0.00011 \text { to } \\
0.00053)\end{array}$ & $\begin{array}{c}(0.00003 \text { to } \\
0.00007)\end{array}$ & $\begin{array}{c}(0.00343 \text { to } \\
0.00510)\end{array}$ \\
\hline & 0.00892 & 0.00284 & -0.00002 & 0.00002 & 0.00608 \\
\hline \multirow[t]{2}{*}{ Lower limbs } & $\begin{array}{c}(0.00821 \text { to } \\
0.00963)\end{array}$ & $\begin{array}{c}(0.00163 \text { to } \\
0.00406)\end{array}$ & $\begin{array}{c}(-0.00006 \text { to } \\
0.00002)\end{array}$ & $\begin{array}{c}(-0.00001 \text { to } \\
0.00005)\end{array}$ & $\begin{array}{c}(0.00500 \text { to } \\
0.00716)\end{array}$ \\
\hline & 0.00720 & 0.00200 & -0.00001 & 0.00001 & 0.00520 \\
\hline Spine & $\begin{array}{c}(0.00653 \text { to } \\
0.00788)\end{array}$ & $\begin{array}{c}(0.00081 \text { to } \\
0.00319)\end{array}$ & $\begin{array}{c}(-0.00004 \text { to } \\
0.00002)\end{array}$ & $\begin{array}{c}(-0.00002 \text { to } \\
0.00004)\end{array}$ & $\begin{array}{c}(0.00416 \text { to } \\
0.00625)\end{array}$ \\
\hline TBLH & $\begin{array}{c}0.00690 \\
(0.00637 \text { to } \\
0.00743)\end{array}$ & $\begin{array}{c}0.00170 \\
(0.00084 \text { to } \\
0.00256)\end{array}$ & $\begin{array}{c}-0.00002 \\
(-0.00006 \text { to } \\
0.00083)\end{array}$ & $\begin{array}{c}0.00002 \\
(0.000002 \text { to } \\
0.00005)\end{array}$ & $\begin{array}{c}0.00520 \\
(0.00442 \text { to } \\
0.00598)\end{array}$ \\
\hline \multicolumn{6}{|l|}{ aBMD } \\
\hline & 0.00304 & 0.00125 & 0.00001 & -0.00001 & 0.00179 \\
\hline Upper limbs & $\begin{array}{c}(0.00233 \text { to } \\
0.00376)\end{array}$ & $\begin{array}{c}(0.00049 \text { to } \\
0.00201)\end{array}$ & $\begin{array}{c}(-0.00003 \text { to } \\
0.00004)\end{array}$ & $\begin{array}{c}(-0.00003 \text { to } \\
0.00001)\end{array}$ & $\begin{array}{c}(0.00120 \text { to } \\
0.00238)\end{array}$ \\
\hline & 0.00409 & 0.00172 & 0.00001 & -0.00001 & 0.00237 \\
\hline Lower limbs & $\begin{array}{c}(0.00317 \text { to } \\
0.00501)\end{array}$ & $\begin{array}{c}(0.00076 \text { to } \\
0.00267)\end{array}$ & $\begin{array}{c}(-0.00003 \text { to } \\
0.00005)\end{array}$ & $\begin{array}{c}(-0.00003 \text { to } \\
0.00001)\end{array}$ & $\begin{array}{c}(0.00162 \text { to } \\
0.00313)\end{array}$ \\
\hline & 0.00558 & 0.00356 & 0.00003 & -0.00003 & 0.00203 \\
\hline Spine & $\begin{array}{c}(0.00447 \text { to } \\
0.00670)\end{array}$ & $\begin{array}{l}(0.00227 \text { to } \\
0.00484)\end{array}$ & $\begin{array}{c}(-0.00007 \text { to } \\
0.00013)\end{array}$ & $\begin{array}{c}(-0.00006 \text { to } \\
0.00001)\end{array}$ & $\begin{array}{c}(0.00115 \text { to } \\
0.00290)\end{array}$ \\
\hline & 0.00361 & 0.00145 & 0.00001 & -0.00001 & 0.00216 \\
\hline TBLH & $\begin{array}{c}(0.00285 \text { to } \\
0.00436)\end{array}$ & $\begin{array}{c}(0.00069 \text { to } \\
0.00220)\end{array}$ & $\begin{array}{c}(-0.00003 \text { to } \\
0.00005)\end{array}$ & $\begin{array}{c}(-0.00003 \text { to } \\
0.00001)\end{array}$ & $\begin{array}{c}(0.00152 \text { to } \\
0.00279)\end{array}$ \\
\hline
\end{tabular}

Analysis performed by sex and adjusted for sport modality. Significant values are in bold and the effect of somatic maturation on aBMD mediated by LST is presented in "Pure Indirect Effect".

A

Percentage of mediation in boys: $70.8 \%$ (95\%Cl: $56.1 \%$ to $85.5 \%$ ) Percentage of mediation in girls: $58.8 \%(95 \% \mathrm{Cl}: 39.2 \%$ to $78.5 \%)$

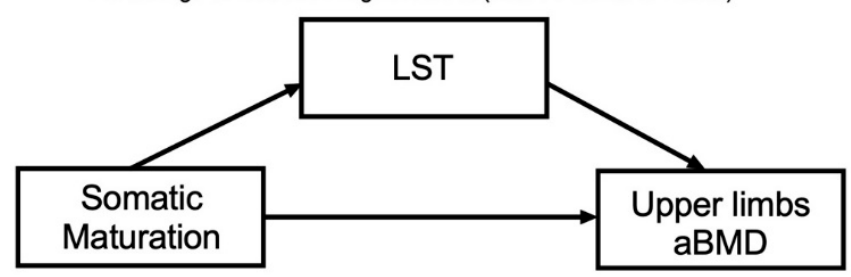

C

Percentage of mediation in boys: $72.2 \%(95 \% \mathrm{Cl}: 56.8 \%$ to $87.7 \%)$ Percentage of mediation in girls: $36.3 \%$ ( $95 \% \mathrm{Cl}: 20.3 \%$ to $52.3 \%)$

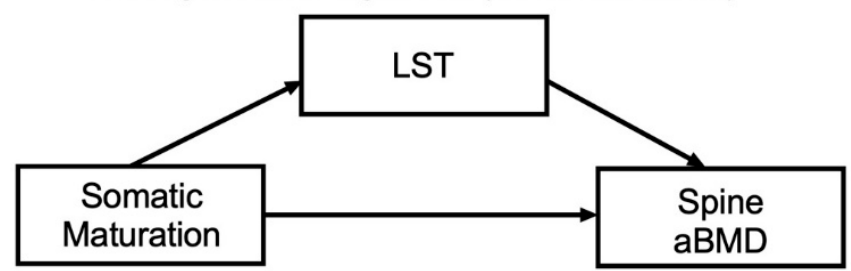

B

Percentage of mediation in boys: $68.1 \%(95 \% \mathrm{Cl}: 55.5 \%$ to $80.8 \%)$ Percentage of mediation in girls: $58.0 \%(95 \% \mathrm{Cl}: 39.6 \%$ to $76.4 \%)$

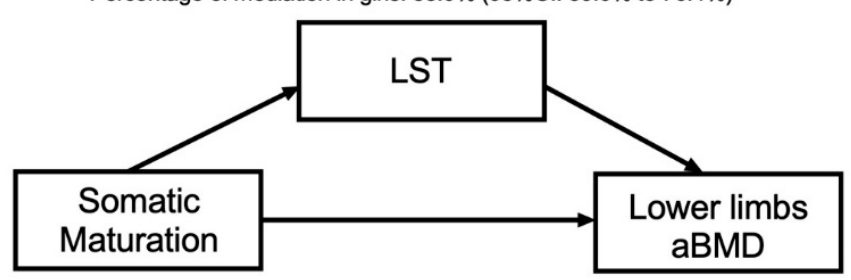

D

Percentage of mediation in boys: $75.4 \%$ (95\% Cl: $63.4 \%$ to $87.1 \%$ ) Percentage of mediation in girls: $59.8 \%(95 \% \mathrm{Cl}: 43.0 \%$ to $76.7 \%)$

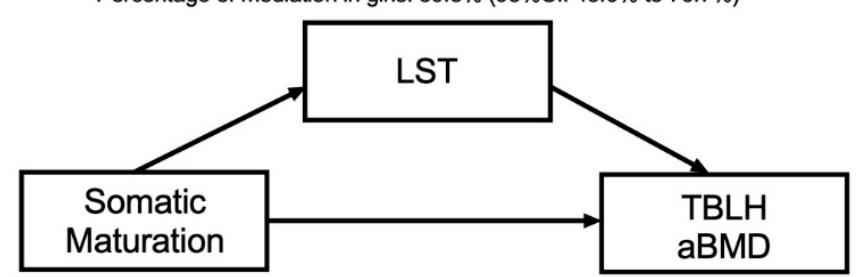

Figure 2. Mediation models of LST in the relationship between somatic maturation and aBMD sites according to sex and after adjusting for sport modality. 
Table 4 and Figure 3 present the mediation models by sport participation. Our results show that for both the sport and non-sport groups, LST mediated the association between somatic maturation and aBMD in the upper limbs (64.4\% for sport group and $68.3 \%$ for non-sport group), lower limbs (60.4\% for sport group and $85.6 \%$ for non-sport group), spine $(61.4 \%$ for sport group and $51.6 \%$ for non-sport group) and TBLH (65.6\% for sport group and $82.2 \%$ for non-sport group). There was a direct effect of somatic maturation on all aBMD variables in the sport and non-sport groups, except for the lower limbs $(p=0.239)$ and TBLH $(p=0.106)$ in the non-sport group.

Table 4. Mediation models of the association between somatic maturation and aBMD by LST according to sports participation status.

\begin{tabular}{|c|c|c|c|c|c|}
\hline & Total Effect & $\begin{array}{l}\text { Controlled } \\
\text { Direct Effect }\end{array}$ & $\begin{array}{l}\text { Reference } \\
\text { Interaction }\end{array}$ & $\begin{array}{l}\text { Mediated } \\
\text { Interaction }\end{array}$ & $\begin{array}{l}\text { Pure Indirect } \\
\text { Effect }\end{array}$ \\
\hline \multicolumn{6}{|l|}{$\begin{array}{c}\text { aBMD } \\
\text { Sport group }\end{array}$} \\
\hline \multirow{3}{*}{ Upper limbs } & 0.00592 & 0.00211 & -0.00005 & 0.00005 & 0.00381 \\
\hline & $\begin{array}{c}(0.00536 \text { to } \\
0.00648)\end{array}$ & $\begin{array}{l}(0.00123 \text { to } \\
0.00299)\end{array}$ & $\begin{array}{c}(-0.00010 \text { to } \\
0.00033)\end{array}$ & $\begin{array}{l}(0.00002 \text { to } \\
0.00007)\end{array}$ & $\begin{array}{c}(0.00306 \text { to } \\
0.00456)\end{array}$ \\
\hline & 0.00885 & 0.00350 & -0.00003 & 0.00003 & 0.00535 \\
\hline \multirow[t]{2}{*}{ Lower limbs } & $\begin{array}{c}(0.00814 \text { to } \\
0.00957)\end{array}$ & $\begin{array}{l}(0.00241 \text { to } \\
0.00459)\end{array}$ & $\begin{array}{c}(-0.00007 \text { to } \\
0.00001)\end{array}$ & $\begin{array}{c}(-0.000003 \text { to } \\
0.00006)\end{array}$ & $\begin{array}{c}(0.00441 \text { to } \\
0.00630)\end{array}$ \\
\hline & 0.00702 & 0.00271 & -0.000004 & 0.000004 & 0.00431 \\
\hline \multirow[t]{2}{*}{ Spine } & $\begin{array}{c}\text { (0.00631 to } \\
0.00773)\end{array}$ & $\begin{array}{c}(0.00156 \text { to } \\
0.00285)\end{array}$ & $\begin{array}{c}(-0.00004 \text { to } \\
0.00003)\end{array}$ & $\begin{array}{c}(-0.00005 \text { to } \\
0.00003)\end{array}$ & $\begin{array}{c}(0.00335 \text { to } \\
0.00527)\end{array}$ \\
\hline & 0.00688 & 0.00237 & -0.00002 & 0.00002 & 0.00451 \\
\hline TBLH & $\begin{array}{c}(0.00634 \text { to } \\
0.00741)\end{array}$ & $\begin{array}{c}(0.00159 \text { to } \\
0.00315)\end{array}$ & $\begin{array}{c}(-0.00005 \text { to } \\
0.00001)\end{array}$ & $\begin{array}{c}(0.000001 \text { to } \\
0.00004)\end{array}$ & $\begin{array}{c}(0.00381 \text { to } \\
0.00520)\end{array}$ \\
\hline \multicolumn{6}{|l|}{$\begin{array}{l}\text { Non-sport } \\
\text { group }\end{array}$} \\
\hline \multirow{3}{*}{ Upper limbs } & 0.00041 & 0.00013 & -0.0000001 & 0.0000001 & 0.00028 \\
\hline & $\begin{array}{c}(0.00034 \text { to } \\
0.00048)\end{array}$ & $\begin{array}{l}(0.00003 \text { to } \\
0.00023)\end{array}$ & $\begin{array}{c}(-0.000002 \text { to } \\
0.000002)\end{array}$ & $\begin{array}{l}(-0.0000002 \\
\text { to } 0.0000003)\end{array}$ & $\begin{array}{c}(0.00020 \text { to } \\
0.00036)\end{array}$ \\
\hline & 0.00056 & 0.00008 & 0.0000002 & -0.0000002 & 0.00048 \\
\hline \multirow[t]{2}{*}{ Lower limbs } & $\begin{array}{c}(0.00046 \text { to } \\
0.00066)\end{array}$ & $\begin{array}{c}(-0.00005 \text { to } \\
0.00021)\end{array}$ & $\begin{array}{c}(-0.000005 \text { to } \\
0.000006)\end{array}$ & $\begin{array}{c}(-0.000001 \text { to } \\
0.0000001)\end{array}$ & $\begin{array}{l}(0.00036 \text { to } \\
0.00060)\end{array}$ \\
\hline & 0.00064 & 0.00031 & 0.0000002 & 0.0000002 & 0.00033 \\
\hline Spine & $\begin{array}{c}(0.00054 \text { to } \\
0.00074)\end{array}$ & $\begin{array}{l}(0.00016 \text { to } \\
0.00046)\end{array}$ & $\begin{array}{c}(-0.000006 \text { to } \\
0.000006)\end{array}$ & $\begin{array}{l}(-0.0000006 \\
\text { to } 0.0000001)\end{array}$ & $\begin{array}{c}(0.00021 \text { to } \\
0.00045)\end{array}$ \\
\hline TBLH & $\begin{array}{c}0.00046 \\
(0.00038 \text { to } \\
0.00054)\end{array}$ & $\begin{array}{c}0.00008 \\
(-0.00002 \text { to } \\
0.00018)\end{array}$ & $\begin{array}{c}0.0000001 \\
(-0.000003 \text { to } \\
0.000003)\end{array}$ & $\begin{array}{c}-0.0000001 \\
(-0.0000004 \\
\text { to } 0.0000001)\end{array}$ & $\begin{array}{c}0.00038 \\
(0.00029 \text { to } \\
0.00047)\end{array}$ \\
\hline
\end{tabular}

Analysis performed by sport participation and adjusted for sex and sport modality. Significant values are in bold and the effect of somatic maturation on aBMD mediated by LST is presented in "Pure Indirect Effect". 
A

Percentage of mediation in sport group: $64.4 \%(95 \% \mathrm{Cl}: 51.0 \%$ to $77.7 \%)$ Percentage of mediation in non-sport group: $68.3 \%$ ( $95 \% \mathrm{Cl}$ : $47.0 \%$ to $89.6 \%$ )

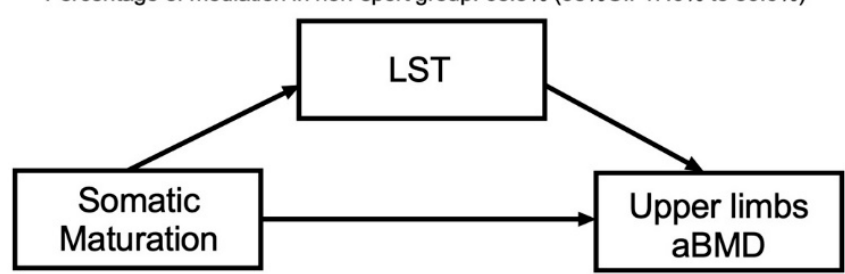

C

Percentage of mediation in sport group: $61.4 \%$ (95\%Cl: $46.9 \%$ to $75.6 \%)$ Percentage of mediation in non-sport group: $51.6 \%(95 \% \mathrm{Cl}: 32.1 \%$ to $71.1 \%)$

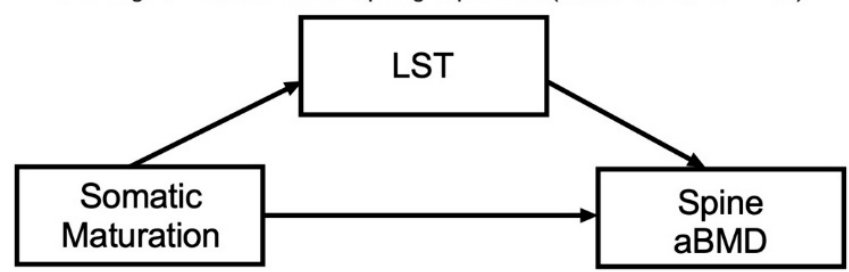

B

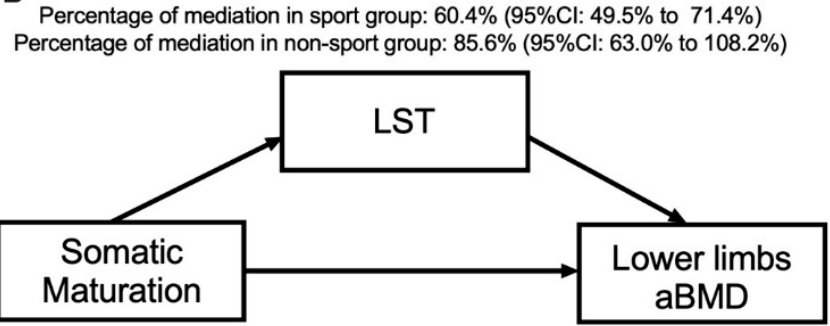

D

Percentage of mediation in sport group: $65.6 \%(95 \% \mathrm{Cl}: 55.3 \%$ to $75.9 \%)$ Percentage of mediation in non-sport group: $82.2 \%$ (95\% Cl: $62.1 \%$ to $102.3 \%$ )

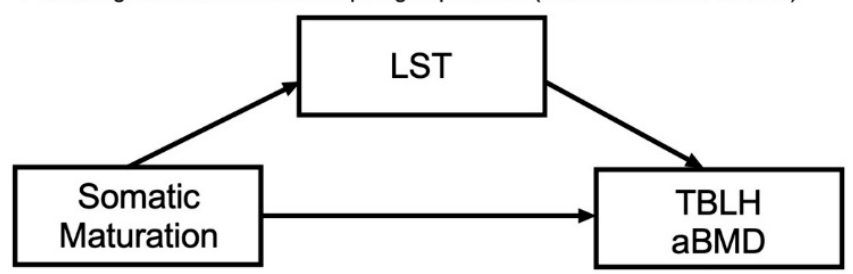

Figure 3. Mediation models of LST in the relationship between somatic maturation and aBMD sites according to sport participation status and after adjusting for sport modality and sex.

\section{Discussion}

This study examined the mediating role of LST in the relationship between somatic maturation and aBMD in adolescents, stratified by sex and by sport participation. The main findings were that LST mediated the association between somatic maturation and aBMD at all skeletal sites (upper limbs, lower limbs, spine and TBLH) in male and female adolescents regardless of sport participation. Furthermore, the direct association between somatic maturation and aBMD remained significant after accounting for LST as a mediating variable, except for lower limbs and TBLH in the non-sport group.

This study created a theoretical model assessing the mediating role of LST on the association between somatic maturation and aBMD. In the analysis by sex, our results showed that the LST mediated the association between somatic maturation and aBMD at all skeletal sites in both sexes. Therefore, somatic maturation influences aBMD by influencing LST, which then influences aBMD through the mechanical load applied in the bone matrix, consequently increasing the recruitment of osteogenic cells [25]. This is apparent in males and females, which corroborates a previous theory suggesting that bone adapts according to the necessity of adaptation caused by external factors in males and females, including greater LST [26].

Our findings support those from the study by Jackowski et al. [12] and by Vlachopoulos et al. [10] which found that muscle variables were a significant predictor of bone outcomes, including aBMD. In the study by Jackowski et al., the authors also found, in the Saskatchewan Pediatric Bone Mineral Accrual Study, that the mechanical loading of muscle contractions causes bone adaptations and that the peak of lean tissue precedes the peak of bone mineral content accrual, following the maturation sequence to attain PHV and peak tissue (peak height velocity, peak lean mass, peak weight velocity and peak fat mass/peak of bone mass, simultaneously, in that order) [27,28], indicating a possible causality of this association. Therefore, biological maturation is associated with gains in LST, which, theoretically, precede and are partially responsible for the gains in bone mineral density in males and females [12].

Boys showed a higher percentage of mediation by LST at all skeletal sites $(68.1 \%$ to $75.4 \%$ in boys vs. $36.3 \%$ to $59.8 \%$ in girls). In fact, it is well documented that males have higher LST than females mainly during adolescence and maintained in adulthood [29], 
which would justify this percentage, as well as higher values of aBMD in males observed in the literature. Furthermore, in females, body fat is more important in the prediction of aBMD than in males, mainly in the spine $[30,31]$ (skeletal site with lower percentage of mediation by LST in the study in females), partially due to the synthesis of estrogen in the adipose tissue, which promotes cortical and trabecular bone accrual [32].

The mediating effect of LST in the association between somatic maturation and aBMD at all skeletal sites was also observed in both the sport and non-sport groups, reinforcing the positive effect of LST on aBMD explained above. For this reason, LST is usually used as a covariate in studies focusing on bone, growth and sport participation [33]. However, there was no direct effect on the lower limbs and total body in the non-sport group. Despite it being established in the literature that adolescents who practice sports have greater muscle recruitment and more weight-bearing activities, which enhance aBMD gain [23,34-39], it is possible that sports participation can modify the association between somatic maturation and aBMD by other mechanisms beyond LST, such as hormonal [40], while non-sport practitioners' aBMD at these skeletal sites may depend on LST to a greater extent compared to sport practitioners.

Another possible explanation refers to the fact that the magnitude of the total, direct and indirect effects of somatic maturation with aBMD is lower in the non-sport group compared to the sport group, which could explain the higher percentage of mediation by LST in this group. This indicates a possible greater effect of sport participation in the association between somatic maturation and aBMD, both directly and indirectly through LST. However, more studies, particularly longitudinal, are needed to verify this mediation effect.

This study has practical implications such as showing the importance of applying strategies for the development of LST (muscle tissue) in order to enhance the gains of aBMD derived from the maturation process. Besides that, taking into account that biological maturation is considered an important confounder in growth studies of bone health among sports sciences [27], these findings reinforce the importance for studies involving aBMD variables in adolescents to consider both somatic maturation and LST as important predictors and confounding variables.

Limitations of this study include that it did not adjust the analyses by habitual physical activity and nutritional status, which are potential confounders [10,41]. In addition, our sample included adolescents between 10 and 18 years of age, and the indicator of somatic maturation might have a bias of estimation in samples with a large age range (outside the optimal band of estimation) [42]. In addition, despite the adjustment by sport modality, we acknowledge that sports affect aBMD differently, and for this reason, studies analyzing each sport modality separately should be encouraged. Lastly, similar analyses involving adolescents from different countries investigating sex differences should be encouraged due to the differences in the growth and development of children and adolescents in developed and developing countries [43]. In contrast, the strengths of the study include that it included a large sample of more than 600 adolescents with indicators of objectively measured aBMD and LST and reliable assessment of somatic maturation.

\section{Conclusions}

In summary, the present study shows that LST mediates the relationship between somatic maturation and aBMD of different skeletal sites in male and female adolescents, regardless of involvement in organized sports. These findings suggest that the potential mediating effect of LST in the association between somatic maturation and aBMD is similar in males and females; however, the mediation magnitude seems to be affected by sport participation in the lower limbs and TBLH. Finally, our findings highlight the role of improving LST to mitigate the association of somatic maturation with aBMD and future studies should be encouraged in order to understand other potential mediators of this association. 
Author Contributions: Conceptualization, R.R.A., A.O.W., S.M.-V., L.G.-M., E.U.-G., R.A.F. and D.V.; methodology, R.R.A., A.O.W., S.M.-V. and R.A.F.; formal analysis, R.R.A., A.O.W. and D.V.; investigation, R.R.A., A.O.W., S.M.-V., L.G.-M., E.U.-G., R.A.F. and D.V.; resources, R.A.F. and D.V.; data curation, R.R.A. and A.O.W.; writing-original draft preparation, R.R.A., A.O.W. and D.V.; writing-review and editing, R.R.A., A.O.W., S.M.-V., L.G.-M., E.U.-G., A.M.C., R.A.F. and D.V.; visualization, R.R.A., A.O.W., S.M.-V., L.G.-M., E.U.-G., A.M.C., R.A.F. and D.V.; supervision, D.V.; project administration, R.A.F.; funding acquisition, R.R.A., A.O.W., S.M.-V., R.A.F. and D.V. All authors have read and agreed to the published version of the manuscript.

Funding: This research was funded by the São Paulo Research Foundation (FAPESP) (FAPESP Process 2013/06963-5, 2015/13543-8, 2016/06920-2, 2017/09182-5, 2018/24164-6 and 2015/19710-3); A.O.W. received a Grant from the FAPESP (2017/27234-2); S.M.-V. received a grant from the FAPESP (2016/20354-0); L.G.-M. was funded by "La Caixa" Foundation within the Junior Leader fellowship programme (ID 100010434; code LCF/BQ/PR19/11700007).

Institutional Review Board Statement: The study was conducted according to the guidelines of the Declaration of Helsinki, and approved by the Institutional Review Board (or Ethics Committee) of São Paulo State University (protocol code 02891112.6.0000.5402 on 07/05/2012 and 1.677.938/2016 on $12 / 08 / 2016)$.

Informed Consent Statement: Informed consent was obtained from all participants involved in the study and from their parents or guardians.

Data Availability Statement: Due to data privacy, the data presented in this study are available upon request from the corresponding author and Principal Investigator of the ABCD Growth study.

Acknowledgments: The authors gratefully acknowledge the São Paulo Research Foundation (FAPESP), Coordenação de Aperfeiçoamento de Pessoal de Nivel Superior-Brasil (CAPES), Conselho Nacional de Desenvolvimento Científico e Tecnológico $(\mathrm{CNPq})$ and the effort of the participants and their parents and coaches. The authors also thank all researchers of Laboratory of InVestigation in Exercise (LIVE) for their support in data collection.

Conflicts of Interest: The authors declare no conflict of interest.

\section{References}

1. Malina, R.M.; Bouchard, C.; Bar-Or, O. Growth, Maturation, and Physical Activity, 2nd ed.; Human Kinetics: Champaign, IL, USA, 2004; ISBN 0880118822.

2. Lynch, K.R.; Anokye, N.K.; Vlachopoulos, D.; Barbieri, F.A.; Turi-Lynch, B.C.; Codogno, J.S.; Agostinete, R.R.; Fernandes, R.A. Impact of sports participation on incidence of bone traumatic fractures and health-care costs among adolescents: ABCD—Growth Study. Phys. Sportsmed. 2019, 1-6. [CrossRef] [PubMed]

3. Christoffersen, T.; Emaus, N.; Dennison, E.; Furberg, A.-S.; Gracia-Marco, L.; Grimnes, G.; Nilsen, O.A.; Vlachopoulos, D.; Winther, A.; Ahmed, L.A. The association between childhood fractures and adolescence bone outcomes: A population-based study, the Tromsø Study, Fit Futures. Osteoporos. Int. 2018, 29, 441-450. [CrossRef]

4. Schoenau, E.; Frost, H.M. The "Muscle-Bone Unit" in Children and Adolescents. Calcif. Tissue Int. 2002, 70, 405-407. [CrossRef] [PubMed]

5. Ross, M.H.; Pawlina, W. Chapter 8 Bone. In Histology: A Text and Atlas: With Correlated Cell and Molecular Biology; Lippincott Williams \& Wilkins, a Wolters Kluwer Business: Baltimore, MD, USA, 2011; pp. 218-242. ISBN 978-0-7817-7200-6.

6. Ross, M.H.; Pawlina, W. Chapter 11 Muscle Tisse. In Histology: A Text and Atlas: With Correlated Cell and Molecular Biology; Lippincott Williams \& Wilkins, a Wolters Kluwer Business: Baltimore, MD, USA, 2011; pp. 310-331. ISBN 978-0-7817-7200-6.

7. Baxter-Jones, A.D.; Faulkner, R.A.; Forwood, M.R.; Mirwald, R.L.; Bailey, D.A. Bone mineral accrual from 8 to 30 years of age: An estimation of peak bone mass. J. Bone Miner. Res. 2011, 26, 1729-1739. [CrossRef]

8. Ubago-Guisado, E.; Vlachopoulos, D.; Barker, A.R.; Christoffersen, T.; Metcalf, B.; Gracia-Marco, L. Effect of maturational timing on bone health in male adolescent athletes engaged in different sports: The PRO-BONE study. J. Sci. Med. Sport 2019, 22, 253-258. [CrossRef]

9. Jackowski, S.A.; Erlandson, M.C.; Mirwald, R.L.; Faulkner, R.A.; Bailey, D.A.; Kontulainen, S.A.; Cooper, D.M.L.; Baxter-Jones, A.D.G. Effect of maturational timing on bone mineral content accrual from childhood to adulthood: Evidence from 15years of longitudinal data. Bone 2011, 48, 1178-1185. [CrossRef]

10. Vlachopoulos, D.; Ubago-Guisado, E.; Barker, A.R.; Metcalf, B.S.; Fatouros, I.G.; Avloniti, A.; Knapp, K.M.; Moreno, L.A.; Williams, C.A.; Gracia-Marco, L. Determinants of Bone Outcomes in Adolescent Athletes at Baseline: The PRO-BONE Study. Med. Sci. Sports Exerc. 2017, 49, 1389-1396. [CrossRef] [PubMed]

11. Frost, H.M.; Schönau, E. The "muscle-bone unit" in children and adolescents: A 2000 overview. J. Pediatr. Endocrinol. Metab. 2000, 13, 571-590. [CrossRef] 
12. Jackowski, S.A.; Faulkner, R.A.; Farthing, J.P.; Kontulainen, S.A.; Beck, T.J.; Baxter-Jones, A.D.G. Peak lean tissue mass accrual precedes changes in bone strength indices at the proximal femur during the pubertal growth spurt. Bone 2009, 44, 1186-1190. [CrossRef]

13. Kuh, D.; Muthuri, S.G.; Moore, A.; Cole, T.J.; Adams, J.E.; Cooper, C.; Hardy, R.; Ward, K.A. Pubertal timing and bone phenotype in early old age: Findings from a British birth cohort study. Int. J. Epidemiol. 2016, 45, 1113-1124. [CrossRef]

14. Silva, C.C.; Goldberg, T.B.L.; Nga, H.S.; Kurokawa, C.S.; Capela, R.C.; Teixeira, A.S.; Dalmas, J.C. Impact of skeletal maturation on bone metabolism biomarkers and bone mineral density in healthy Brazilian male adolescents. J. Pediatr. Rio J. 2011, 87, 450-456. [CrossRef]

15. Agostinete, R.R.; Ito, I.H.; Kemper, H.; Pastre, C.M.; Rodrigues-Júnior, M.A.; Luiz-de-Marco, R.; Fernandes, R.A. Somatic maturation and the relationship between bone mineral variables and types of sports among adolescents: Cross-sectional study. Sao Paulo Med. J. 2017, 135, 253-259. [CrossRef] [PubMed]

16. Ubago-Guisado, E.; Vlachopoulos, D.; Ferreira de Moraes, A.C.; Torres-Costoso, A.; Wilkinson, K.; Metcalf, B.; Sánchez-Sánchez, J.; Gallardo, L.; Gracia-Marco, L. Lean mass explains the association between muscular fitness and bone outcomes in 13-year-old boys. Acta Paediatr. 2017, 106, 1658-1665. [CrossRef]

17. Vlachopoulos, D.; Barker, A.R.; Ubago-Guisado, E.; Fatouros, I.G.; Knapp, K.M.; Williams, C.A.; Gracia-Marco, L. Longitudinal Adaptations of Bone Mass, Geometry, and Metabolism in Adolescent Male Athletes: The PRO-BONE Study. J. Bone Miner. Res. 2017, 32, 2269-2277. [CrossRef]

18. International Society for Clinical Densitometry. Skeletal Health Assessment. In Children from Infancy to Adolescence; ISCD: Middletown, CT, USA, 2013.

19. Agostinete, R.R.; Vlachopoulos, D.; Werneck, A.O.; Maillane-Vanegas, S.; Lynch, K.R.; Naughton, G.; Fernandes, R.A. Bone accrual over 18 months of participation in different loading sports during adolescence. Arch. Osteoporos. 2020, 15, 64. [CrossRef]

20. Gordon, C.; Chumlea, W.; Roche, A. Stature, recumbent length, and weight. In Anthropometric Standardization Reference Manual; Human Kinetics Books: Champaign, IL, USA, 1988; pp. 3-8.

21. Moore, S.A.; McKay, H.A.; Macdonald, H.; Nettlefold, L.; Baxter-Jones, A.D.G.; Cameron, N.; Brasher, P.M.A. Enhancing a Somatic Maturity Prediction Model. Med. Sci. Sports Exerc. 2015, 47, 1755-1764. [CrossRef]

22. Valeri, L.; Vanderweele, T.J. Mediation analysis allowing for exposure-mediator interactions and causal interpretation: Theoretical assumptions and implementation with SAS and SPSS macros. Psychol. Methods 2013, 18, 137-150. [CrossRef]

23. Agostinete, R.R.; Fernandes, R.A.; Narciso, P.H.; Maillane-Vanegas, S.; Werneck, A.; Vlachopoulos, D. Categorizing 10 Sports According to Bone and Soft Tissue Profiles in Adolescents. Med. Sci. Sports Exerc. 2020, 52, 2673-2681. [CrossRef]

24. Discacciati, A.; Bellavia, A.; Lee, J.J.; Mazumdar, M.; Valeri, L. Med4way: A Stata command to investigate mediating and interactive mechanisms using the four-way effect decomposition. Int. J. Epidemiol. 2019, 48, 15-20. [CrossRef]

25. Rauch, F.; Bailey, D.A.; Baxter-Jones, A.; Mirwald, R.; Faulkner, R. The "muscle-bone unit" during the pubertal growth spurt. Bone 2004, 34, 771-775. [CrossRef]

26. Frost, H.M. Bone "mass" and the "mechanostat": A proposal. Anat. Rec. 1987, 219, 1-9. [CrossRef]

27. Bailey, D.A.; Baxter-Jones, A.D.G.; Mirwald, R.L.; Faulkner, R.A. Bone growth and exercise studies: The complications of maturation. J. Musculoskelet. Neuronal Interact. 2003, 3, 335-337.

28. Luliano-Burns, S.; Mirwald, R.L.; Bailey, D.A. Timing and magnitude of peak height velocity and peak tissue velocities for early, average, and late maturing boys and girls. Am. J. Hum. Biol. 2001, 13, 1-8. [CrossRef]

29. Guo, S.S.; Chumlea, W.C.; Roche, A.F.; Siervogel, R.M. Age- and maturity-related changes in body composition during adolescence into adulthood: The Fels Longitudinal Study. Int. J. Obes. Relat. Metab. Disord. 1997, 21, 1167-1175. [CrossRef]

30. Cobayashi, F.; Lopes, L.A.; Taddei, J.A.A.C. Bone mineral density in overweight and obese adolescents. J. Pediatr. Rio J. 2005, 81, 337-342. [CrossRef]

31. El Hage, R.P.; Courteix, D.; Benhamou, C.-L.; Jacob, C.; Jaffré, C. Relative importance of lean and fat mass on bone mineral density in a group of adolescent girls and boys. Eur. J. Appl. Physiol. 2009, 105, 759-764. [CrossRef]

32. Schoenau, E.; Neu, C.M.; Rauch, F.; Manz, F. The development of bone strength at the proximal radius during childhood and adolescence. J. Clin. Endocrinol. Metab. 2001, 86, 613-618. [CrossRef] [PubMed]

33. Vlachopoulos, D.; Barker, A.R.; Ubago-Guisado, E.; Williams, C.A.; Gracia-Marco, L. The effect of a high-impact jumping intervention on bone mass, bone stiffness and fitness parameters in adolescent athletes. Arch. Osteoporos. 2018, 13, 128. [CrossRef]

34. Forero-Bogotá, M.A.; Ojeda-Pardo, M.L.; García-Hermoso, A.; Correa-Bautista, J.E.; González-Jiménez, E.; Schmidt-RíoValle, J.; Navarro-Pérez, C.F.; Gracia-Marco, L.; Vlachopoulos, D.; Martínez-Torres, J.; et al. Body Composition, Nutritional Profile and Muscular Fitness Affect Bone Health in a Sample of Schoolchildren from Colombia: The Fuprecol Study. Nutrients 2017, 9, 106. [CrossRef]

35. Lozano-Berges, G.; Matute-Llorente, Á.; González-Agüero, A.; Gómez-Bruton, A.; Gómez-Cabello, A.; Vicente-Rodríguez, G.; Casajús, J.A. Soccer helps build strong bones during growth: A systematic review and meta-analysis. Eur. J. Pediatr. 2018, 177, 295-310. [CrossRef] [PubMed]

36. Ito, I.H.; Kemper, H.C.G.; Agostinete, R.R.; Lynch, K.R.; Christofaro, D.G.D.; Ronque, E.R.; Fernandes, R.A. Impact of Martial Arts (Judo, Karate, and Kung Fu) on Bone Mineral Density Gains in Adolescents of Both Genders: 9-Month Follow-Up. Pediatr. Exerc. Sci. 2017, 29, 496-503. [CrossRef] 
37. Kohrt, W.M.; Bloomfield, S.A.; Little, K.D.; Nelson, M.E.; Yingling, V.R. American College of Sports Medicine American College of Sports Medicine Position Stand: Physical activity and bone health. Med. Sci. Sports Exerc. 2004, 36, 1985-1996. [CrossRef]

38. Jürimäe, J.; Gruodyte-Raciene, R.; Baxter-Jones, A.D.G. Effects of Gymnastics Activities on Bone Accrual during Growth: A Systematic Review. J. Sports Sci. Med. 2018, 17, 245-258.

39. Tenforde, A.S.; Fredericson, M. Influence of sports participation on bone health in the young athlete: A review of the literature. PMR 2011, 3, 861-867. [CrossRef]

40. Eliakim, A.; Nemet, D.; Cooper, D.M. Exercise, Training and the GH-IGF-I Axis. In The Endocrine System in Sports and Exercise; Blackwell Publishing Ltd.: Oxford, UK, 2005; pp. 165-179.

41. Constable, A.M.; Vlachopoulos, D.; Barker, A.R.; Moore, S.A.; Soininen, S.; Haapala, E.A.; Väistö, J.; Westgate, K.; Brage, S.; Mahonen, A.; et al. The independent and interactive associations of physical activity intensity and vitamin D status with bone mineral density in prepubertal children: The PANIC Study. Osteoporos. Int. 2021. [CrossRef]

42. Kozieł, S.M.; Malina, R.M. Modified Maturity Offset Prediction Equations: Validation in Independent Longitudinal Samples of Boys and Girls. Sports Med. 2018, 48, 221-236. [CrossRef] [PubMed]

43. Natale, V.; Rajagopalan, A. Worldwide variation in human growth and the World Health Organization growth standards: A systematic review. BMJ Open 2014, 4, e003735. [CrossRef] 